\title{
Synthesis of OmpA Protein of Escherichia coli K12 in Bacillus subtilis
}

\author{
By PAULI KALLIO, ${ }^{1}$ MARJO SIMONEN, ${ }^{2}$ ILKKA PALVA ${ }^{1}$ AND \\ MATTI SARVAS ${ }^{2 *}$ \\ ${ }^{1}$ Recombinant DNA Laboratory, University of Helsinki, SF-00380 Helsinki, Finland \\ ${ }^{2}$ National Public Health Institute, SF-00280 Helsinki, Finland
}

(Received 4 July 1985; revised 3 September 1985)

\begin{abstract}
We have inserted a C-terminally truncated gene of the major outer membrane protein OmpA of Escherichia coli downstream from the promoter and signal sequence of the secretory $\alpha$-amylase of Bacillus amyloliquefaciens in a secretion vector of Bacillus subtilis. B. subtilis transformed with the hybrid plasmid synthesized a protein that was immunologically identified as OmpA. All the protein was present in the particulate fraction. The size of the protein compared to the peptide synthesized in vitro from the same template indicated that the $\alpha$-amylase derived signal peptide was not removed; this was verified by $\mathrm{N}$-terminal amino acid sequence determination. The lack of cleavage suggests that there was little or no translocation of OmpA protein across the cytoplasmic membrane. This is an unexpected difference compared with periplasmic proteins, which were both secreted and processed when fused to the same signal peptide. A requirement of a specific component for the export of outer membrane proteins is suggested.
\end{abstract}

\section{INTRODUCTION}

For many purposes it would be highly desirable to obtain outer member (OM) proteins of Gram-negative bacteria free of lipopolysaccharide and other components of the cell envelope. Such pure proteins would be especially useful for evaluating their potential use as vaccines. Their purification is, however, tedious and seldom achievable under mild conditions (for a review, see Lugtenberg \& van Alphen, 1983) largely due to their amphipathic or hydrophobic character, which leads to aggregation with other proteins and glycolipids of the cell envelope (Hofstra \& Dankert, 1980; Kuusi et al., 1981 ; Lugtenberg \& van Alphen, 1983). Furthermore, at least two classes of major OM proteins - the pore forming porins and the OmpA protein - have a specific affinity to lipopolysaccharide (van Alphen et al., 1979; Lugtenberg \& van Alphen, 1983; Osborn \& Wu, 1980; Schindler \& Rosenbusch, 1981; Schweizer et al., 1978; Yamada \& Mizushima, 1980), so that these proteins cannot be separated from lipopolysaccharide without extensive denaturation (Furukawa et al., 1979; Overbeeke et al., 1980; see also Lugtenberg \& van Alphen, 1983; Vaara \& Nikaido, 1984).

A possible way to obtain lipopolysaccharide-free OM proteins would be to clone the corresponding genes into a Gram-positive bacterium. Bacillus subtilis is a host in which a set of cloning vectors is available. The vectors have been constructed from the plasmid pUB 110 by insertion of the promoter and signal sequence of the secretory $\alpha$-amylase of $B$. amyloliquefaciens (Palva et al., 1982, 1983). The signal sequence is immediately followed by a cloning site so that the cloned protein as produced is fused to the signal peptide of the $\alpha$-amylase (Fig. 2). Foreign secretory proteins, among them the periplasmic $\beta$-lactamase of Escherichia coli (Palva et al., 1982), can be effectively synthesized and secreted in this system.

We have tested the feasibility of producing OM proteins of Gram-negative bacteria in this system using the OmpA protein of $E$. coli as a model. OM proteins are made as precursors with

Abbreviation: OM, outer membrane. 
cleavable signal peptides, and their translocation across the cytoplasmic membrane is believed to take place via the secretory pathway also used by periplasmic proteins (Silhavy et al., 1983). The secretion vector described was therefore expected to provide the $o m p A$ gene with both a promoter for synthesis in $B$. subtilis and a signal sequence already shown to be effective for translocation of a periplasmic protein in $B$. subtilis.

In this paper we show that the omp $A$ gene cloned in the secretion vector indeed directed the synthesis of this protein in $B$. subtilis. However, the signal peptide was not cleaved, suggesting that there was little or no translocation across the cytoplasmic membrane. This surprising finding may indicate a fundamental difference between OM proteins and other exoproteins and suggests that the Bacillus secretory mechanism lacks an element required for the processing of OM proteins.

\section{METHODS}

Bacteria and plasmids. B. subtilis IH6140, a prototrophic derivative of B. subtilis Marburg 1 A289 (Steinmetz et al., 1976) with a reduced level of exoprotease (Palva et al., 1983), was from our collection. E. coli K12 strain EH222 ( $\mathrm{Hrs}^{-} \mathrm{Hrm}^{-}$rec $A \mathrm{Gal}^{-}$Pro- $\mathrm{Leu}^{-} \mathrm{Str}^{-} \mathrm{F}^{-}$) was a derivative of $E$. coli $\mathrm{HB} 101$ (Boyer \& Roulland-Dussoix, 1969). E. coli $\mathrm{K} 12$ strain UH100 (Thi- pyrD gltA galK $\mathrm{Str}^{-} \mathrm{Trp}^{-}$recA ompA) (Bremer et al., 1980) was from Ulf Henning, Max-Planck-Institut, Tübingen, FRG.

The plasmids used were pBR322 (Bolivar et al., $1977 a, b$ ) and pUB110 (Gryczan et al., 1978). The plasmid pTU100 (Bremer et al., 1980) is a derivative of pSC101 (Cohen \& Chang, 1973) containing the ompA gene of E. coli K 12. It was a kind gift from Ulf Henning. pKTH 132 , pK TH55 and pKTH60 are secretion vectors derived from pUB110 by inserting into the plasmid the promoter and signal sequence of the $\alpha$-amylase gene of $B$. amyloliquefaciens. The signal sequence is followed by a cloning site in all reading frames (Lundström, 1985; Palva et al., 1982, 1983; Palva, 1983; I. Palva, personal communication). pKTH132 has termination signals for both translation (Pettersson et al., 1983) and transcription (Lundström, 1985) downstream from the cloning site.

Growth conditions. The bacteria were grown in L-broth (Lennox, 1955) either on plates or in liquid cultures on a rotary shaker with vigorous shaking at $37^{\circ} \mathrm{C}$. The antibiotics used were ampicillin $\left(100 \mu \mathrm{g} \mathrm{ml}^{-1}\right)$, tetracycline $\left(12.5 \mu \mathrm{g} \mathrm{ml}^{-1}\right)$ and kanamycin $\left(10 \mu \mathrm{g} \mathrm{m}^{-1}\right)$. When the expression of $o m p A$ fragments was studied in $B$. subtilis, the bacteria were grown in twofold concentrated L-broth and supplemented with kanamycin and with potato extract which was prepared as follows. Peeled potatoes were cut, ground and centrifuged at $27000 \mathrm{~g}$, at $4{ }^{\circ} \mathrm{C}$ for $30 \mathrm{~min}$. The supernatant was collected and its $\mathrm{pH}$ was lowered to 3.0 with $6 \mathrm{M}-\mathrm{HCl}$. The precipitate was removed by centrifugation at $20000 \mathrm{~g}$, at $4^{\circ} \mathrm{C}$ for $20 \mathrm{~min}$. The $\mathrm{pH}$ of the supernatant was adjusted to $7 \cdot 0$. The extract was heated to $80^{\circ} \mathrm{C}$ for $10 \mathrm{~min}$, cooled to room temperature and centrifuged at $20000 \mathrm{~g}$, at $4{ }^{\circ} \mathrm{C}$ for $10 \mathrm{~min}$. The supernatant was collected, sterilized by filtration and stored at $-20^{\circ} \mathrm{C}$. Potato extract increased the yield of both $\alpha$-amylase and foreign proteins encoded by genes inserted into the secretion vector. Concentration of the extract in L-broth was optimized by assaying the amount of $E$. coli $\beta$-lactamase secreted from $B$. subtilis containing the bla gene in a secretion vector (Palva et al., 1982). Usually $30 \mu \mathrm{l}$ potato extract per $\mathrm{ml} \mathrm{L}$-broth was used.

Cell fractionation. B. subtilis strains were grown to early stationary phase. Cells were collected by centrifugation. The cell-free supernatant (culture medium) was made $10 \mathrm{~mm}$ with EDTA and $1 \mathrm{~mm}$ with phenylmethylsulphonyl fluoride. Cells were suspended in $20 \mathrm{~mm}$-potassium phosphate, $15 \mathrm{~mm}-\mathrm{MgCl}_{2}, \mathrm{pH} 7 \cdot 0$, containing $20 \%$ (w/v) sucrose and $1 \mathrm{mg}$ lysozyme $\mathrm{ml}^{-1}$ and incubated at $37^{\circ} \mathrm{C}$ until the cells turned into protoplasts (usually $30 \mathrm{~min}$ ). The protoplasts were centrifuged and suspended in $50 \mathrm{mM}$-Tris $/ \mathrm{HCl}, \mathrm{pH} 7 \cdot 0$, and sonicated briefly to break the protoplasts. Membranes (particulate fractions) were collected by centrifugation at $100000 \mathrm{~g}$ for $30 \mathrm{~min}$ at $4{ }^{\circ} \mathrm{C}$ and suspended in $50 \mathrm{~mm}$-Tris/ $\mathrm{HCl}, \mathrm{pH} \mathrm{7.0.} \mathrm{The} \mathrm{supernatant} \mathrm{was} \mathrm{used} \mathrm{as} \mathrm{the} \mathrm{fraction} \mathrm{of} \mathrm{soluble} \mathrm{cellular} \mathrm{proteins.} \mathrm{The}$ cell envelope preparation of $E$. coli was made as described by Nurminen et al. (1976). When treated with trypsin, a cell envelope suspension containing $1 \mathrm{mg}$ protein per $\mathrm{ml}$ of $50 \mathrm{~mm}$-HEPES, $10 \mathrm{~mm}$-EDTA, $2 \%(\mathrm{v} / \mathrm{v}$ ) Triton X-100, $\mathrm{pH} 8.4$, was incubated with $2 \mu \mathrm{g}$ trypsin $\mathrm{ml}^{-1}$ for $2 \mathrm{~h}$ at $37^{\circ} \mathrm{C}$.

Isolation of $O m p A_{228}$ protein from B. subtilis. For the determination of the $\mathrm{N}$-terminal amino acid sequence, the OmpA $A_{228}$ protein was isolated from the membrane fraction of $B$. subtilis. The membranes were solubilized in $5 \%$ Triton X-100, $50 \mathrm{~mm}$-EDTA, $50 \mathrm{~mm}$-Tris $/ \mathrm{HCl}, \mathrm{pH} 8.0$, at $0{ }^{\circ} \mathrm{C}$. OmpA was pelleted by centrifugation $(20000 \mathrm{~g}$, $20 \mathrm{~min}, 4^{\circ} \mathrm{C}$ ); most other proteins remained in the supernatant. The solubilization and centrifugation were repeated. The pellet was then solubilized in $2 \%(\mathrm{w} / \mathrm{v})$ Sarkosyl, $1 \mathrm{~mm}-\mathrm{EDTA}, 50 \mathrm{~mm}-\mathrm{Tris} / \mathrm{HCl}$, pH $8 \cdot 0$, and centrifuged as above. OmpA 228 remained in the supernatant. To remove the rest of the contaminating proteins the supernatant was electrophoresed in a preparative SDS gel and $\mathrm{OmpA}_{228}$ was eluted from the gel as below.

Determination of the $\mathrm{N}$-terminal amino acid sequence. Purified $\mathrm{OmpA} \mathrm{A}_{28}$ was dissolved in $100 \mu \mathrm{l}$ dimethylallylamine/trifluoroacetic acid buffer, pH 9.5 (in propanol/water, $3: 2, \mathrm{v} / \mathrm{v}$ ) and subjected to manual Edman degradation (Peterson et al., 1972). The released phenylthiohydantoin amino acids were, after conversion in $25 \%$ (v/v) trifluoroacetic acid for $30 \mathrm{~min}$ at $55^{\circ} \mathrm{C}$, analysed by HPLC on a Spherisorb S5 ODS2 column, using a gradient of acetonitrile in $50 \mathrm{~mm}$-sodium acetate, $\mathrm{pH} 4.8$ (Zimmerman et al., 1977). 
Recombinant DNA techniques. Plasmids were isolated on a large scale from $E$. coli as described by Clewell \& Helinski (1969) and from B. subtilis as described by Palva et al. (1981). Some batches were further purified in a neutral sucrose gradient (Palva et al., 1981).

E. coli EH222 and B. subtilis IH6140 were transformed as described by Mandel \& Higa (1970) and Gryczan et al. (1978), respectively.

The methods of Birnboim \& Doly (1979), Klein et al. (1980) and Barnes (1977) were used to screen for the presence of plasmids and their approximate sizes. The method of Barnes (1977) was modified for B. subtilis by treating the bacteria with $2 \mathrm{mg}$ lysozyme $\mathrm{ml}^{-1}$ for $30 \mathrm{~min}$ at $37^{\circ} \mathrm{C}$ before the SDS/NaOH/EDTA treatment. Exonuclease treatments and DNA linker ligations were done as described by Palva et al. (1982).

DNA fragments were sequenced according to Maxam \& Gilbert (1980).

In vitro transcription-translation assay. This was done according to Fuchs (1976) and immunoprecipitation according to Sarvas et al. (1978). The proteins were labelled with $\left[{ }^{35}\right.$ S]methionine during the in vitro synthesis.

Preparation of antisera against OmpA protein. Most of the antisera that had been raised in rabbits against purified OmpA protein did not detect the $\mathrm{N}$-terminal trypsin fragment $(24 \mathrm{kDa})$ of OmpA, although they detected the complete OmpA protein very well. This means that most of the antibodies were directed against determinants of the C-terminal part. Because this part was not present in the truncated OmpA protein coded by the cloned genes used, we prepared antisera against the $\mathrm{N}$-terminal trypsin fragment of OmpA as follows. Envelope preparation of E. coli $\mathrm{O} 111$ (Nurminen et al., 1976) (about $5 \mathrm{mg}$ ) was treated with trypsin and electrophoresed in $15 \%$ preparative SDS-acrylamide gel (Sarvas \& Nurminen, 1985). Protein bands were made visible by submerging the gel in $0 \cdot 1 \mathrm{M}-$ $\mathrm{KCl}$. The $24 \mathrm{kDa}$ OmpA fragment was cut out and eluted with $0.05 \%$ SDS at $37^{\circ} \mathrm{C}$ overnight. SDS was removed by dialysis and the protein concentrated by vacuum dialysis. Rabbits were immunized by injecting a total of $60 \mu \mathrm{g}$ protein (as three injections at two week intervals) in Freund's complete adjuvant into the popliteal lymph nodes (Leinonen, 1985). The antisera thus obtained detected, by the immunoblotting method, the complete OmpA protein, the $24 \mathrm{kDa}$ trypsin fragment of OmpA and the OmpA synthesized in B. subtilis.

Gel electrophoresis. Plasmids and DNA fragments were analysed in agarose gels (Sharp et al., 1973), using a flat bed apparatus, or in vertical gradient polyacrylamide gels (Jeppesen, 1980).

Proteins were analysed in SDS-PAGE gels (Laemmli, 1970; Sarvas \& Nurminen, 1985) and then either stained with Coomassie brilliant blue or immunoblotted (Sarvas \& Nurminen, 1985; Towbin et al., 1979) and visualized by autoradiography using ${ }^{125} \mathrm{I}$-labelled protein A from Staphylococcus aureus.

Enzymes and chemicals. Restriction enzymes were from BRL, New England Biolabs, Amersham or BoehringerMannheim; they were used according to the manufacturers' instructions. T4 DNA ligase and T4 polynucleotide kinase were from BRL, SI nuclease and E. coli exonuclease III were purchased from Calbiochem and New England Biolabs, respectively. Reverse transcriptase was a kind gift from J. Beard, Life Sciences Inc., USA. DNA linkers were obtained from BRL.

\section{RESULTS}

\section{Modification of the ompA gene}

Synthesis of a large amount of OmpA protein is lethal in E.coli (Bremer et al., 1980). For this reason the $o m p A$ gene had initially not been cloned in a high copy number plasmid, in which the synthesis of OmpA from the efficient $\mathrm{ompA}$ promoter would be lethal, but instead in pTU100 (Fig. 1), a derivative of the low copy number vector pSC101 (Bremer et al., 1980). Since $B$. subtilis does not usually start transcription from $E$. coli promoters, the ompA gene was not expected to be expressed or to be lethal even in a high copy number plasmid in this host. To facilitate the isolation of plasmid DNA needed for the modifications described below we subcloned an ompA gene fragment into the high copy number plasmid pUB110 of B. subtilis.

In the plasmid pTU100 the omp $A$ gene is located in two Bam HI fragments (Fig. 1) (Bremer $e t$ al., 1980, 1982). The $1.78 \mathrm{~kb}$ fragment contains the promoter, the signal sequence and the first 228 codons, whereas the $1.83 \mathrm{~kb}$ fragment codes for the last 98 residues of the OmpA protein. This C-terminal part of OmpA is believed to be entirely located on the periplasmic side of the OM. Since the $1.78 \mathrm{~kb}$ fragment was known to be sufficient to direct the synthesis and incorporation of the truncated OmpA protein in the OM in E. coli, we decided to use it as the basis for further constructions. That fragment was subcloned into pUB110. The resulting hybrid plasmid was designated pKTH42 (Fig. 1).

To construct an $o m p A$ derivative lacking the promoter region, the plasmid pKTH42 was cleaved at the unique $A v a \mathrm{I}$ site (Fig. 1) located at about $1.2 \mathrm{~kb}$ upstream from the $o m p A$ promoter. After partial digestion with $E$. coli exonuclease III and S1 nuclease, fill-in with reverse 


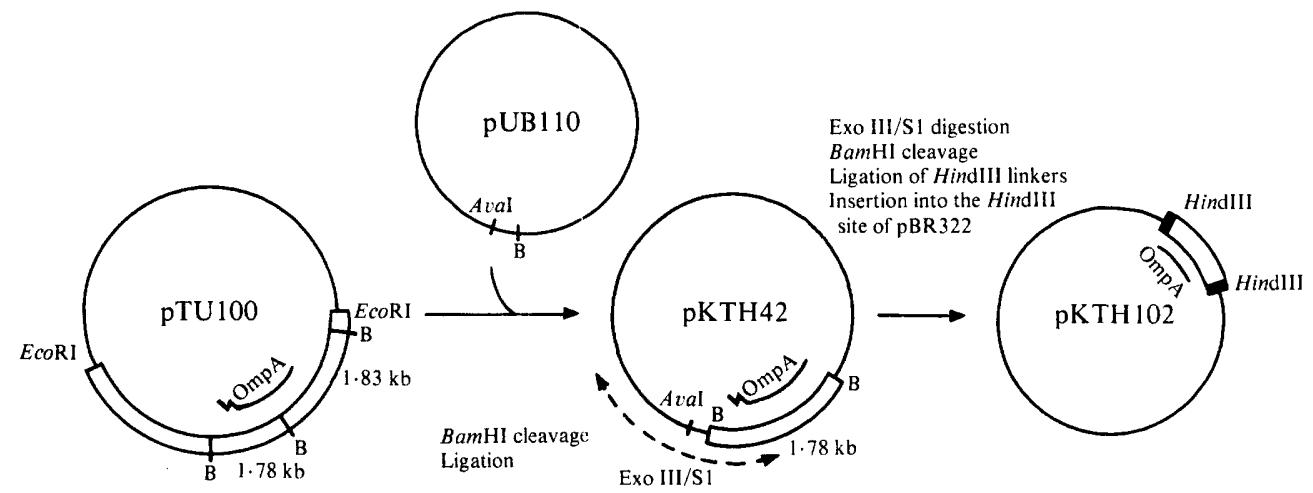

Fig. 1. Modification of $o m p A$ gene. The Bam HI fragment of pTU100 coding for the amino terminus (up to residue 228) of OmpA protein was inserted into the BamHI site of pUB110. The promoter and signal sequence of ompA were removed by an Exo III/S1 nuclease treatment starting from the AvaI site of pKTH42. The truncated ompA gene was inserted into pBR322 by the aid of HindIII linkers. For details see the text. B, Bam HI site; $\boldsymbol{n}$, signal peptide of OmpA.

transcriptase and addition of an Eco RI linker the plasmid was cut with BamHI; the Eco RI$B a m \mathrm{HI}$ fragments were cloned in pBR322. This cloning excluded any omp $A$ fragment that would retain a functional promoter after the exonuclease treatment because that would have led to lethal expression of $o m p A$ from the high copy number plasmid pBR322.

The extent of nuclease digestion in the plasmids isolated from the surviving transformants was analysed by gradient polyacrylamide gel electrophoresis after cutting the plasmid with restriction enzymes $\mathrm{HpaI}$, which has a unique site in the ompA gene fragment (Beck \& Bremer, 1980 ), and $E c o$ RI. Several plasmids of the desired size were picked up and their $5^{\prime}$ end sequences determined. The promoter, signal sequence and seven $\mathrm{N}$-terminal codons of $o m p A$ were deleted in one of the plasmids (Fig. 2). From this plasmid the omp $A$ fragment was cut out with Eco RI and BamHI. HindIII linkers were ligated and the fragment was inserted into the HindIII site of pBR322. This gave us an ompA construction (pKTH102; Fig. 1) coding for amino acid residues 8 to 228 of mature OmpA protein.

\section{Insertion of the omp A fragment into the secretion vector}

As described above, the plasmid pKTH102 carried a DNA fragment coding for the amino acid residues 8 to $228\left(\mathrm{OmpA}_{228}\right)$ of OmpA protein flanked by HindIII linkers (Fig. 1). The fragment was cut out with HindIII endonuclease and inserted into the HindIII site of the secretion vector (pK TH132) (Fig. 2). The insert was thus placed between the signal sequence of $\alpha$-amylase and a stretch of DNA containing a synthetic oligonucleotide with translational stop codon TGA in all reading frames (Pettersson et al., 1983) and the transcription termination signal of the $\alpha$-amylase gene (Lundström, 1985) (see Fig. 2). Hybrid plasmids containing an insert of the right size were screened by the methods of Birnboim \& Doly (1979) and Barnes (1977). The orientation of the insert was analysed by restriction endonuclease digestion (ClaI, PvuII; see Fig. 2) followed by electrophoresis of the fragments in agarose gel. The orientation and the reading frame were confirmed by sequencing the region joining the insert and the vector (Fig. 2). The primary translation product is expected to start with the complete signal peptide (31 residues) of $\alpha$-amylase, followed by six linker-derived amino acid residues, then the residues $(8-228)$ of the mature OmpA protein and finally five residues derived from the linker and the synthetic oligonucleotide containing the translational stop codon (Fig. 2).

\section{Synthesis of OmpA protein in B. subtilis}

B. subtilis IH6140 was transformed with the plasmid pKTH158. The presence of OmpA protein was detected by SDS-PAGE of various cellular fractions followed by immunoblotting with anti-OmpA serum. The membrane (particulate) fraction of such a transformant contained 

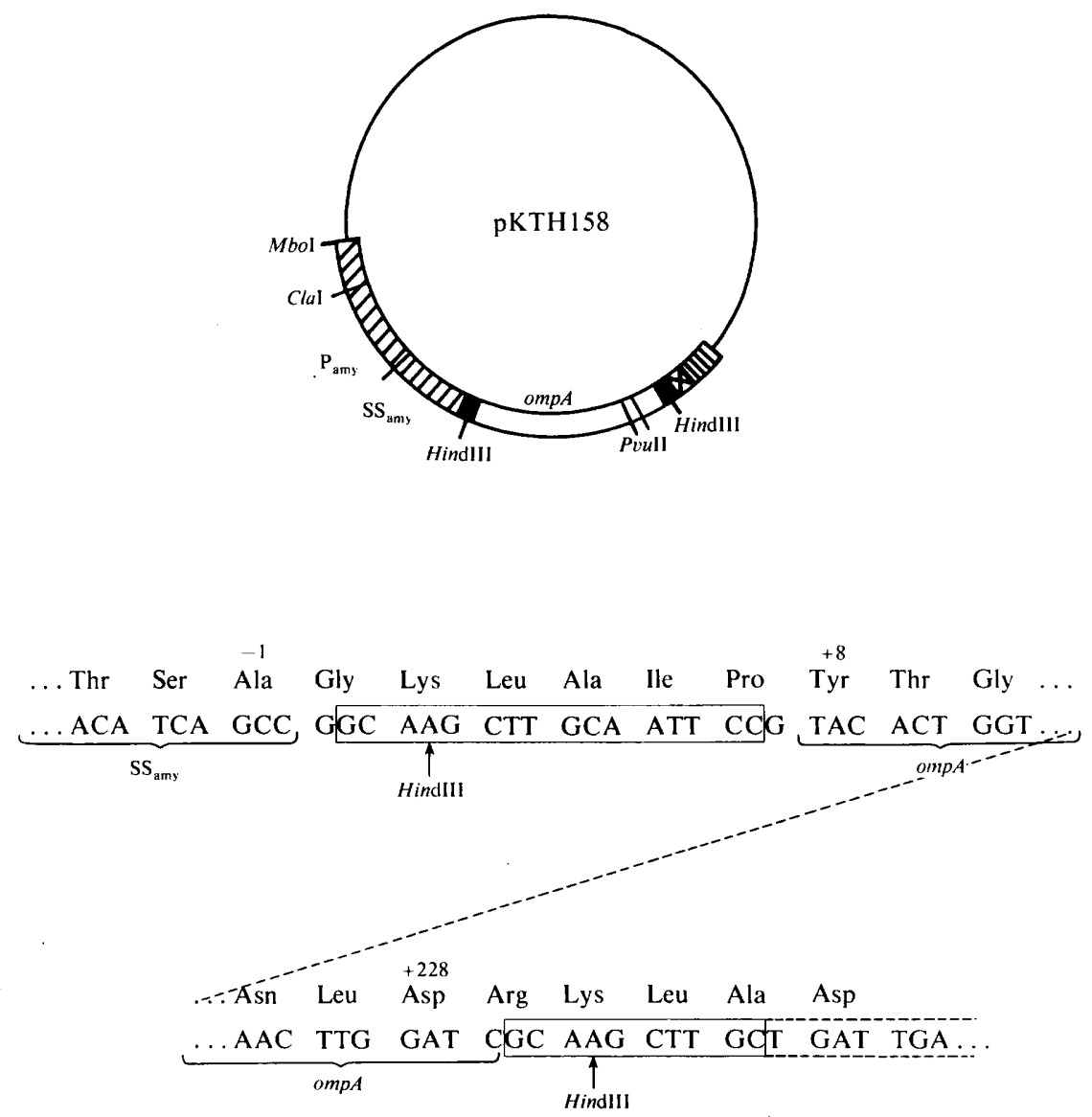

Fig. 2. Truncated ompA gene inserted in the HindIII site of the secretion vector and the nucleotide and amino acid sequences around the junctions. The nucleotides in the solid outline boxes derive from the linkers and those in the dotted outline box derive from the oligonucleotide with the stop codons. -1 is the last amino acid residue of the signal peptide of $\alpha$-amylase $;+8$ and +228 are the respective amino acid residues of mature OmpA protein. $\mathbb{Z Z D}$, DNA of $\alpha$-amylase gene of B. amyloliquefaciens; $\mathrm{P}_{\mathrm{amy}}$, promotor of $\alpha$-amylase gene; SS $_{a m y}$, signal sequence of $\alpha$-amylase gene; $\otimes$, an oligonucleotide with the stop codon TGA in all reading frames; D. transcription termination region of $\alpha$-amylase gene.

a protein labelled with anti-OmpA serum (Fig. 3, lane D). This serum detects specifically the OmpA protein of $E$. coli or its N-terminal trypsin fragment ( $24 \mathrm{kDa}$ ) (lanes B and C). No proteins were labelled with this serum in the membrane preparation of a strain carrying the secretion vector pKTH132 (lane E).

The membranes for Fig. 3 were prepared from cells at the early stationary phase of growth. At that time point the level of OmpA protein was near its maximum (to be shown in detail elsewhere) and the amount of exoproteases, which appear during the stationary phase, was still very small (Millet, 1970; M. Sibakov, personal communication). No OmpA was detected among the soluble cellular proteins or in the culture medium of the pK TH158 transformant (data not shown).

The amount of the OmpA protein synthesized in the B. subtilis transformant was estimated from the immunoblottings by comparing the intensity of the OmpA band with those in envelope preparations of $E$. coli containing known amounts of OmpA protein. Although not exact this evaluation showed that the maximal amount of OmpA produced in the $B$. subtilis cultures was about 1-2 mg per litre of culture. 


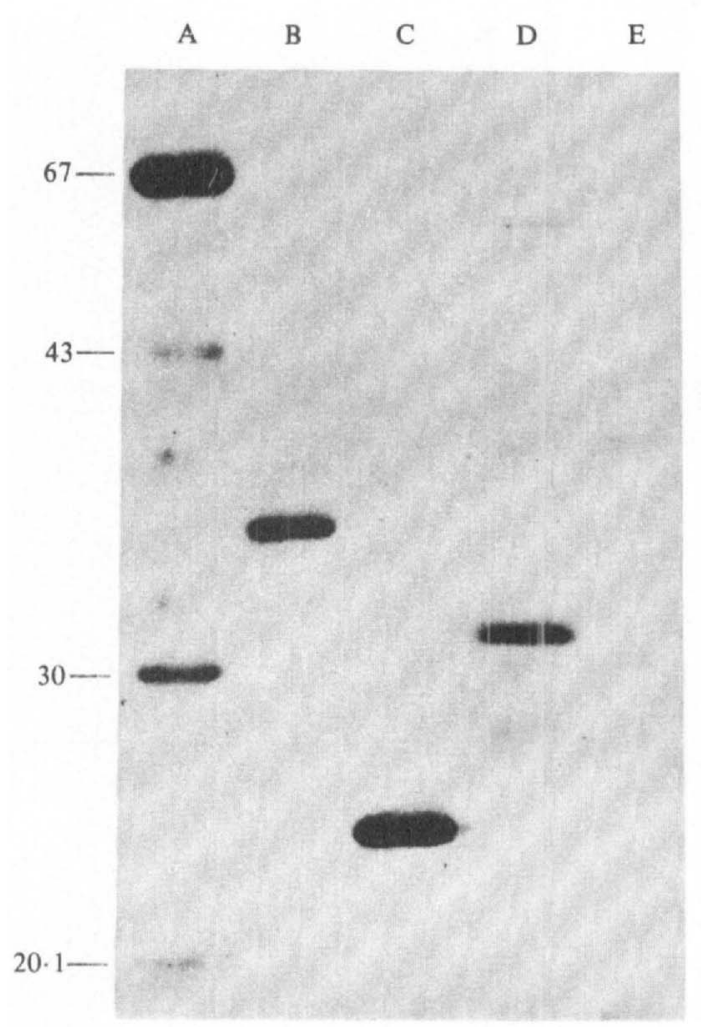

Fig. 3

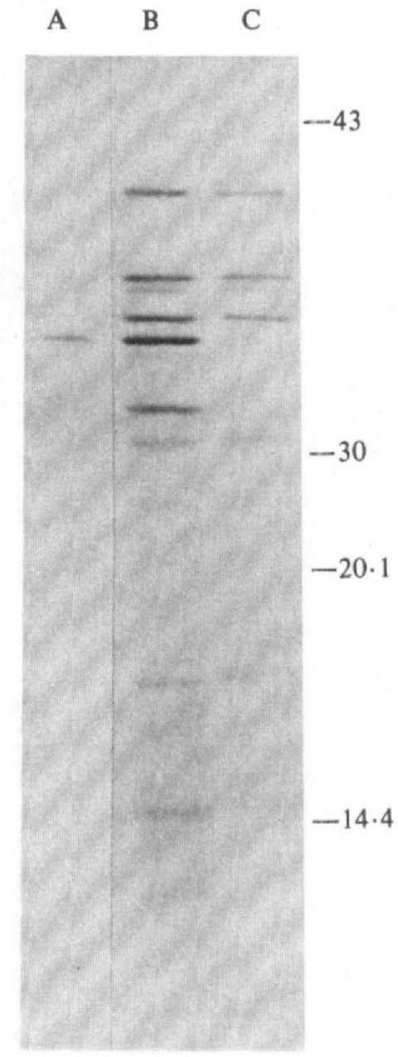

Fig. 4

Fig. 3. Synthesis of OmpA protein in B. subtilis. Immunoblots of: lane A, molecular mass standards (kDa); lane $\mathrm{B}$, envelope of $E$. coli $\mathrm{K} 12$, undigested; lane $\mathrm{C}$, as $\mathrm{B}$, but digested with trypsin; lane D, particulate fraction from $B$. subtilis transformed with $\mathrm{pKTH} 158$; lane $\mathrm{E}$, as $\mathrm{D}$, but the plasmid used in transformation was pKTH132, which contained no ompA insert.

Fig. 4. Synthesis of OmpA protein in an in virro transcription-translation assay. Fluorography of SDSPAGE. The DNA templates used were pKTH158 (lane B) and pKTH132 (lane C). Lane A is an immunoprecipitate of lane B with anti-OmpA serum. The positions of the molecular mass standards $(\mathrm{kDa})$ are indicated on the right-hand side.

\section{Lack of cleavage of the signal peptide}

The expected molecular mass of the primary translation product from the $o m p A_{228}$ gene construction in pK TH158 is about 29000 Da. The removal of the signal peptide would decrease it to about $26000 \mathrm{Da}$. The apparent molecular mass of the OmpA in B. subtilis carrying pKTH 158 was about $31000 \mathrm{Da}$ as estimated by SDS-PAGE (Fig. 3). This is very close to the above estimate of the size of the primary translation product, and much larger than the expected cleavage product.

To obtain the primary translation product in the absence of membranes we synthesized $\mathrm{OmpA}_{228}$ in vitro using pKTH158 DNA as template. In such systems the signal peptide of precursors of secretory proteins is usually not cleaved (Walter \& Blobel, 1981; Ohno-Iwashita et al., 1984). The pK TH 158 template directed the in vitro synthesis of a protein of $31000 \mathrm{Da}$ (Fig. 4, lane B). This protein was precipitated by anti-OmpA serum (lane A). No such protein was present among the proteins synthesized from pKTH132, which lacks the $o m p A_{228}$ insert (lane C). The primary translation product of $o m p A_{228}$ of pKTH158 had thus indeed the same apparent mass as the $\mathrm{OmpA}_{228}$ in the particulate fraction of $B$. subtilis harbouring pKTH158. 
(b)
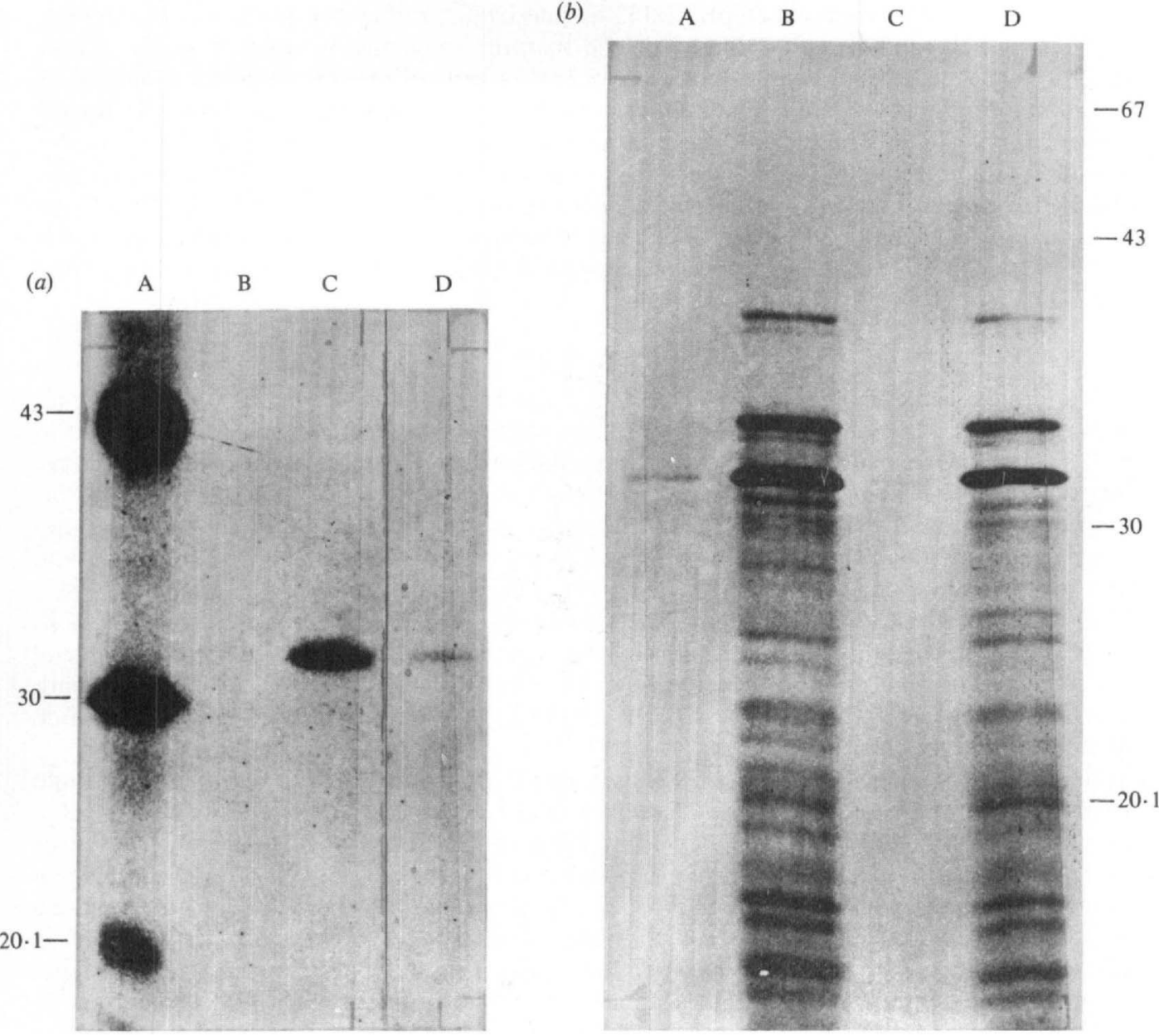

Fig. 5. In vivo and in vitro synthesis of OmpA protein from plasmids pKTH174 and pK TH175. (a) Immunoblots of membrane fractions of B. subtilis carrying either the vector pKTH132 (lane B), pKTH 174 (lane C) or pK TH175 (lane D). Molecular mass standards (kDa) are shown in lane A. (b) In vitro synthesized proteins from pKTH174 (lane D) and pKTH175 (lane B). Lanes A and C are immunoprecipitates with anti-OmpA serum of $B$ and $D$, respectively. The size of the precipitated protein and that of OmpA in the membrane fraction is $32 \mathrm{kDa}$.

These findings strongly suggest that the signal peptide of $\alpha$-amylase was not cleaved off the OmpA protein in B. subtilis.

To confirm that the signal peptide of $\mathrm{OmpA}_{228}$ was indeed not cleaved in $B$. subtilis, the Nterminal amino acid sequence of the protein was determined. When the purified $O \mathrm{mpA}_{228}$ was subjected to four cycles of Edman degradation, a single $\mathrm{N}$-terminal amino acid sequence Met Ile-Gln-Lys was obtained, confirming the purity of the analysed protein. The quantity of the released phenylthiohydantoin amino acids also corresponded to the amount of the degraded protein. The sequence obtained was identical to the $\mathrm{N}$-terminal sequence of the $\alpha$-amylase signal peptide deduced from the DNA sequence (Palva et al., 1981). The result shows that the signal peptide was not cleaved when $\mathrm{OmpA}_{228}$ was synthesized in $B$. subtilis from the plasmid pKTH158.

To make sure that the lack of cleavage of the signal peptide was not due to an unfavourable sequence at the cleavage site in this particular construction (pKTH158), we inserted the $o m p A_{228}$ fragment into two other expression vectors, pK TH55 and pK TH60. They are similar to 
pKTH132, the vector from which pKTH 158 was derived, but they contain before the cloning site four and 17 codons, respectively, of the mature $\alpha$-amylase in addition to the signal sequence. The two plasmids thus obtained, pKTH174 and pKTH175, coded for a protein in which the amino acid sequence around the cleavage site of $\alpha$-amylase signal peptide was natural.

The OmpA proteins produced from both of these vectors in B. subtilis were found in the membrane fraction and had an apparent molecular mass of $32 \mathrm{kDa}$ (Fig. 5). The same size was obtained for these proteins when produced in vitro from DNA templates (Fig. 5). Thus these constructions behaved in an exactly analogous manner to pKTH158, without cleavage of the signal peptide, in spite of the shorter or longer natural amino acid sequence around the cleavage site.

\section{DISCUSSION}

The protein secretion machinery of both eukaryotic (Talmadge et al., 1980a; Gray et al., 1984; Müller et al., 1982) and prokaryotic cells is usually capable of exporting heterologous as well as homologous natural secretory proteins. Many types of foreign secretory proteins have been shown to be exported into the periplasmic space of $E$. coli (see Talmadge et al., $1980 \mathrm{a}$; Pugsley \& Schwartz, 1985). Furthermore, the signal peptides targeting proteins for export are largely exchangeable between proteins from different cells or from different extracytoplasmic locations (Tommassen et al., 1983; Yu et al., 1984; Talmadge et al., 1980 b; Chan et al., 1981; Talmadge \& Gilbert, 1982). Previous observations on the secretion of foreign proteins in $\boldsymbol{B}$. subtilis conform with this general principle. Thus both human and mouse interferons (Palva $e t$ al., 1983; Shiroza et al., 1985) and periplasmic $\beta$-lactamase of E. coli (Palva et al., 1982; Ohmura et al., 1984) were secreted and processed correctly in $B$. subtilis when fused to the signal peptide of the secretory bacilliary $\alpha$-amylase.

The behaviour of the OmpA $A_{228}$ protein in $B$. subtilis is different. Although fused to the same signal peptide of $\alpha$-amylase and synthesized in relatively large amounts, all of the $\operatorname{OmpA}_{228}$ protein synthesized in $B$. subtilis was found in the particulate fraction and was in its precursor form with the signal peptide uncleaved. A possible reason for the lack of cleavage could be an unfavourable amino acid sequence at the expected cleavage site, which in these constructions contained six amino acid residues coded by the HindIII linker. Although much variation is allowed at the cleavage site of signal peptides, there are examples showing that the signal peptidase is not entirely non-specific (Ohmura et al., 1984; Kadonaga et al., 1984; Koshland et al., 1982). To test for this possibility we inserted the $o m p A_{228}$ into two secretion vectors so that $\mathrm{OmpA}_{228}$ became fused to the signal peptide followed by either four (pKTH174) or 17 (pKTH175) residues of the mature $\alpha$-amylase. Thus both these constructions had an intact cleavage site of $\alpha$-amylase signal peptide. A comparison of the OmpA proteins produced from these plasmids in vivo and in vitro showed that the signal peptide was not cleaved (Fig. 5), and thus the lack of cleavage must be due to something other than the sequence at the cleavage site.

The observed lack of cleavage strongly suggests that the protein was not even partially translocated across the cytoplasmic membrane [see Pugsley \& Schwartz (1985) for discussion on processing of the signal peptide and translocation]. This striking difference, compared with the efficient secretion and processing of the $E$. coli $\beta$-lactamase fused to the same signal peptide, indicates that, rather unexpectedly, the export of $O M$ proteins may require specific components not present in the cytoplasmic membrane of $B$. subtilis. We are currently pursuing this interesting possibility by studying in more detail the location and conformation of the OmpA protein made in $B$. subtilis.

No OmpA protein was found in the growth medium of $B$. subtilis harbouring the plasmid pKTH158. The possibility that some OmpA protein could have been secreted into the growth medium and rapidly destroyed by exoproteases, a problem encountered to various degrees with all foreign proteins secreted from B. subtilis (Lundström, 1984; Lundström et al., 1985; Palva et al., 1983; Ulmanen et al., 1985), cannot be formally excluded. However, no OmpA protein was detected in the culture fluid even in the presence of protease inhibitors (phenylmethylsulphonyl fluoride and EDTA or $o$-phenanthrolin) or during exponential phase growth, when there is no detectable protease activity in the growth medium of the host strain used (data not shown). 
In E. coli, the OmpA protein like other OM proteins, must be transported from cytoplasm to its final location in the OM. The mechanism of this transfer is unknown (for a review, see Lugtenberg \& van Alphen, 1983; Pugsley \& Schwartz, 1985). Some hypothetical models (Henning et al., 1983; Osborn \& Wu, 1980) suggest that OM proteins may travel across the periplasmic space in soluble form not bound to membrane structures. Such a form would seemingly be analogous to periplasmic proteins and expected to be secreted - like the $\beta$ lactamase - also across the cytoplasmic membrane of $B$. subtilis when fused to the signal peptide of $\alpha$-amylase. Our failure to find any secreted OmpA protein in the $B$. subtilis cultures does not support this model in its simplest form.

We thank Dr N. Kalkkinen, Recombinant DNA Laboratory, University of Helsinki, for the determination of the N-terminal amino acid sequence, and M. Sc. R. Puohiniemi, National Public Health Institute, Helsinki, for the purification of the $\mathrm{OmpA}_{228}$ protein from B. subtilis.

\section{REFERENCES}

van Alphen, L., Lugtenberg, B., Rietschel, E. TH. \& MoMbers, C. (1979). Architecture of the outer membrane of Escherichia coli K12. Phase transitions of the bacteriophage K 3 receptor complex. European Journal of Biochemistry 101, 571-579.

BARNES, W. M. (1977). Plasmid detection and sizing in single colony lysates. Science 195, 393-394.

BECK, E. \& BREMER, E. (1980). Nucleotide sequence of the gene ompA coding the outer membrane protein II of Escherichia coli K-12. Nucleic Acids Research 8, 3011-3027.

BIRNBOIM, H. C. \& Doly, J. (1979). A rapid alkaline extraction procedure for screening recombinant plasmid DNA. Nucleic Acids Research 7, 15131523.

Bolivar, F., Rodriguez, R. L., Betlach, M. C. \& BOYER, H. W. (1977a). Construction and characterization of new cloning vehicles. I. Ampicillinresistant derivatives of the plasmid pMB9. Gene 2, $75-93$.

Bolivar, F., Rodriguez, R. L., Greene, P. J., BeTlach, M. V., HeYNeckeR, H. L., BOYER, H. W., Crosa, J. H. \& Falkow, S. (1977b). Construction and characterization of new cloning vehicles. II. A multipurpose cloning system. Gene 2, 95-113.

BOYER, H. W. \& Roulland-DussoIX, D. (1969). A complementation analysis of the restriction and modification of DNA in Escherichia coli. Journal of Molecular Biology 41, 459-472.

Bremer, E., Beck, E., Hindennach, I., Sonntag, I. \& HeNNing, U. (1980). Cloned structural gene (ompA) for an integral outer membrane protein of Escherichia coli K-12. Localization on hybrid plasmid pTU100 and expression of a fragment of the gene. Molecular and General Genetics 179, 13-20.

Bremer, E., Cole, S. T., Hindennach, I., Henning, U., Beck, E., Kurz, Ch. \& Schaller, H. (1982). Export of a protein into the outer membrane of Escherichia coli $\mathrm{K}-12$. Stable incorporation of the ompA protein requires less than 193 amino-terminal amino-acid residues. European Journal of Biochemistry 122, 223-231.

Chan, S. J., Weiss, J., Konrad, M., White, T., Bahl, C., Yu, S.-D., Marks, D. \& Steiner, D. F. (1981). Biosynthesis and periplasmic segregation of human proinsulin in Escherichia coli K-12. Proceedings of the National Academy of Sciences of the United States of America 78, 5401-5405.
Clewell, D. B. \& HelinsKi, D. R. (1969). Supercoiled circular DNA-protein complex in Escherichia coli: purification and induced conversion to an open circular DNA form. Proceedings of the National Academy of Sciences of the United States of America 62, 1159-1166.

Cohen, S. N. \& Chang, A. C. Y. (1973). Recircularization and autonomous replication of a sheared $\mathrm{R}$ factor DNA segment in Escherichia coli transformants. Proceedings of the National Academy of Sciences of the United States of America 70, 12931297.

Fuchs, E. (1976). The interdependence of magnesium with spermidine and phosphoenolpyruvate in an enzyme-synthesizing system in vitro. European Journal of Biochemistry 63, 15-22.

Furukawa, H., Yamada, H. \& Mizushima, S. (1979). Interaction of bacteriophage T4 with reconstituted cell envelopes of Escherichia coli K-12. Journal of Bacteriology 140, 1071-1080.

Gray, G. L., McKeown, K. A., Jones, A. J. S., SeeburG, P. H. \& HeyneckeR, H. L. (1984). Pseudomonas aeruginosa secretes and correctly processes human growth hormone. Biotechnology 2, 161-165.

Gryczan, T., Contente, S. \& Dubnau, D. (1978). Characterization of Staphylococcus aureus plasmids introduced by transformation into Bacillus subtilis. Journal of Bacteriology 134, 318-329.

Henning, U., Cole, S. T., Bremer, E., Hindennach, I. \& Schaller, H. (1983). Gene fusions using the ompA gene coding for a major outer membrane protein of Escherichia coli K-12. European Journal of Biochemistry 136, 233-240.

Hofstra, H. \& Dankert, J. (1980). Preparation and quantitative determination of antibodies against major outer membrane proteins of Escherichia coli O26K60. Journal of General Microbiology 117, 437447.

JEPPESEN, P. G. N. (1980). Separation and isolation of DNA fragments using linear polyacrylamide gradient gel electrophoresis. Methods in Enzymology 65, 305-319.

Kadonaga, J. T., Gautier, A. E., Straus, D. R., Charles, A. D., Edge, M. D. \& Knowles, J. R. (1984). The role of the $\beta$-lactamase signal sequence in the secretion of proteins by Escherichia coli. Journal of Biological Chemistry 259, 2149-2154. 
Klein, R. D., Selsing, E. \& Wflls, R. D. (1980). A rapid microscale technique for isolation of recombinant plasmid DNA suitable for restriction enzyme analysis. Plasmid 3, 88.91

Koshland, D., Sauer, R. T. \& Botstein, D. (1982). Diverse effects of mutations in the signal sequence on the secretion of $\beta$-lactamase in Salmonella typhimurium. Cell 30, 903914.

KuUsi, N., Nurminen, M. \& Sarvas, M. (1981). Immunochemical characterization of major outer membrane components from Salmonella typhimurium. Infection and Immunity 33, 750-757.

LAEMMLI, U. K. (1970). Cleavage of structural proteins during the assembly of the head of bacteriophage T4. Nature, London 227, 680-685.

LEINONEN, M. (1985). Serological methods for the study of bacterial surface antigens. In Enterobacterial Surface Antigens: Methods for Molecular Characterization, pp. 179-206. Edited by T. K. K. Korhonen, E. A. Dawes \& P. H. Mäkelä. Amsterdam: Elsevier.

LENNOX, E. S. (1955). Transduction of linked genetic characters of the host by bacteriophage Pl. Virology 1, 190-206.

LUgtenberg, B. \& VAN AlPhen, L. (1983). Molecular architecture and functioning of the outer membrane of Escherichia coli and other gram-negative bacteria. Biochimica et biophysica acta 737, 51-115.

LUNDSTRÖM, K. (1984). Expression of the vesicular stomatitis virus membrane glycoprotein gene in Bacillus subtilis. FEMS Microbiology Letters 23, 65 70 .

LUNDSTRÖM, K. (1985). Expression of viral membrane protein genes in Bacillus subtilis. $\mathrm{PhD}$ thesis, University of Helsinki.

Lundström, K., Palva, I., KäÄriäinen, L., Garoff, H., Sarvas, M. \& Pettersson, R. F. (1985). Secretion of Semliki Forest virus membrane protein E1 from Bacillus subtilis. Virus Research 2, 69-83.

Mandel, M. \& HigA, A. (1970). Calcium-dependent bacteriophage DNA infection. Journal of Molecular Biology 53, 159-162.

MaXam, A. M. \& Gilbert, W. (1980). Sequencing endlabeled DNA with base-specific chemical cleavages. Methods in Enzy'mology 65, 499-560.

MiLlet, J. (1970). Characterization of proteinases excreted by Bacillus subtilis Marburg strain during sporulation. Journal of Applied Bacteriology 33, 207219.

Müller, M., Ibrahimi, I., Chang, C. N., Walter. P. \& BLOBEL, G. (1982). A bacterial secretory protein requires signal recognition particle for translocation across mammalian endoplasmic reticulum. Journal of Biological Chemistry 257, 11860-11863.

Nurminen, M., Lounatmaa, K., Sarvas, M., MÄKEL Ä, P. H. \& NAKAE, T. (1976). Bacteriophageresistant mutants of Salmonella typhimurium deficient in two major outer membrane proteins. Journal of Bacteriology 127, 941-955.

Ohmura, K., Nakamura, K., Yamazaki, H., SHIRoZA, T., Yamane, K., Jigami, Y., Tanaka, H., Yoda, K., Yamasaki, M. \& Tamura, G. (1984). Length and structural effect of signal peptides derived from Bacillus subtilis $\alpha$-amylase on secretion of Escherichia coli $\beta$-lactamase in $B$. subtilis cells. Nucleic Acids Research 12, 5307-5319.

OhNo-Iwashita, Y., Wolfe, P., Ito, K. \& Wickner,
W. (1984). Processing of preproteins by liposomes bearing leader peptidase. Biochemistry 23, 6178 6184.

Osborn, M. J. \& Wu, H. C. P. (1980). Proteins of the outer membrane of gram-negative bacteria. Annual Review of Microbiology 34, 369-422.

Overbeeke, N., Van Scharrenburg, G. \& LUgtenBERG, B. (1980). Antigenic relationships between pore proteins of Escherichia coli K-12. European Journal of Biochemistry 110, 247-254.

Palva, I. (1983). Construction of a Bacillus secretion vector. $\mathrm{PhD}$ thesis, University of Helsinki.

Palva, I., Pettersson, R. F., Kalkkinen, N., Lehtovaara, P., Sarvas, M., Söderlund, H., TAKKINEN, K. \& KÄÄRIÄINEN, L. (1981). Nucleotide sequence of the promoter and $\mathrm{NH}_{2}$-terminal signal peptide region of the $\alpha$-amylase gene from Bacillus amyloliquefaciens. Gene 15, 43-51.

Palva, I., Sarvas, M., Lehtovaara, P., Sibakov, M. \& KÄÄRIÄINEN, L. (1982). Secretion of Escherichia coli $\beta$-lactamase from Bacillus subtilis by the aid of $\alpha$ amylase signal sequence. Proceedings of the National Academy of Sciences of the United States of America 79, 5582-5586.

Palva, I., LehtovaAra, P., KäÄriäinen, L., Sibakov, M., Cantell, K., Schein, C. H., Kashiwagi, K. \& WeissmanN, C. (1983). Secretion of interferon by Bacillus subtilis. Gene 22, 229-235.

Peterson, J. D., Nehrlich, S., Oyer, P. E. \& Steiner, D. F. (1972). Determination of the amino acid sequence of the monkey, sheep, and dog proinsulin C-peptides by a semimicro Edman degradation procedure. Journal of Biological Chemistry 247, 48664871.

Pettersson, R. F., Lundström, K., Chattopadhyaya, J. B., Josephson, S., Philipson, L., KäÄRIÄInen, L. \& Palva, I. (1983). Chemical synthesis and molecular cloning of a STOP oligonucleotide encoding UGA translation terminator in all three reading frames. Gene $24,15-27$.

Pugsley, A. P. \& Schwartz, M. (1985). Export and secretion of proteins by bacteria. FEMS Microbiology Reviews 32, 3-38.

SARvaS, M. \& NURminen, M. (1985). Polyacrylamide gel electrophoretic analysis of cell envelope proteins. In Enterobacterial Surface Antigens: Methods for Molecular Characterization, pp. 123-137. Edited by T. K. K. Korhonen, E. A. Dawes \& P. H. Mäkelä. Amsterdam: Elsevier.

Sarvas, M., Hirth, K. P., Fuchs, E. \& Simons, K. (1978). A precursor form of the penicillinase from Bacillus licheniformis. FEBS Letters 95, 76-80.

SCHINDleR, H.-G. \& RosenbusCH, J. P. (1981). Matrix protein in planar membranes: clusters of channels in a native environment and their functional reassembly. Proceedings of the National Academy of Sciences of the United States of America 78, 23022306.

Schweizer, M., Hindennach, I., Garten, W. \& HENNING, U. (1978). Major proteins of the Escherichia coli outer cell envelope membrane. Interaction of protein II with lipopolysaccharide. European Journal of Biochemistry 82, 211-217.

Sharp, P. A., Sugden, B. \& Sambrook, J. (1973). Detection of two restriction endonuclease activities in Haemophilus influenzae using analytical agarose- 
ethidium bromide electrophoresis. Biochemistry 12, 3055-3063.

Shiroza, T., Nakazawa, K., Tashiro, N., Yamane, K., Yanagl, K., Yamasaki, M., Tamura, G., Saito, H., KaWade, Y. \& TANiguchi, T. (1985). Synthesis and secretion of biologically active mouse interferon$\mu$ using a Bacillus subtilis $\alpha$-amylase secretion vector. Gene 34, 1-8.

Silhavy, T. J., Benson, S. A. \& EMr, S. (1983). Mechanism of protein localization. Microbiological Reviews 47, 313-344.

Steinmetz, M., Kunst, K. \& Dedonder, R. (1976). Mapping of mutations affecting synthesis of exocellular enzymes in Bacillus subtilis. Molecular and General Genetics 148, 281-285.

TalmadGe, K. \& Gilbert, W. (1982). Cellular location affects protein stability in Escherichia coli. Proceedings of the National Academy of Sciences of the United States of America 79, 1830-1833.

Talmadge, K., Kaufman, J. \& Gilbert, W. (1980a). Bacteria mature preproinsulin to proinsulin. Proceedings of the National Academy of Sciences of the United States of America 77, 3988-3992.

Talmadge, K., Stahl, S. \& Gilbert, W. (1980 b). Eukaryotic signal sequence transports insulin antigen in Escherichia coli. Proceedings of the National Academy of Sciences of the United States of America 77, 3369-3373.

Tommassen, J., VAN Tol, H. \& Lugtenberg, B. (1983). The ultimate localization of an outer membrane protein of Escherichia coli $\mathrm{K}-12$ is not determined by the signal sequence. EMBO Journal 2, 1275-1279.

Towbin, H., Staehelin, T. \& GoRdon, J. (1979).
Electrophoretic transfer of proteins from polyacrylamide gels to nitrocellulose sheets: procedure and some applications. Proceedings of the National Academy of Sciences of the United States of America 76, 4350-4354.

Ulmanen, I., Lundström, K., LehtovaARa, P., Sarvas, M., Ruohonen, M. \& Palva, I. (1985). Transcription and translation of foreign genes in Bacillus subtilis by the aid of a secretion vector. Journal of Bacteriology 162, 176-182.

VAARA, M. \& NIKAIDO, H. (1984). Molecular organization of bacterial outer membrane. In Handbook of Endotoxin, vol. 1. Chemistry of Endotoxin, pp. 1-45. Edited by E. Th. Rietschel. Amsterdam: Elsevier.

WALTER, P. \& Blobel, G. (1981). Translocation of proteins across the endoplasmic reticulum. III. Signal recognition protein (SRP) causes signal sequence-dependent and site-specific arrest of chain elongation that is released by microsomal membranes. Journal of Cell Biology 91, 557-561.

YAMADA, H. \& MIZUSHIMA, S. (1980). Interaction between major outer membrane protein $(\mathrm{O}-8)$ and lipopolysaccharide in Escherichia coli K12. European Journal of Biochemistry 103, 209-218.

Yu, F., Furukawa, H., Nakamura, K. \& Mizushima, S. (1984). Mechanism of localization of major outer membrane lipoprotein in Escherichia coli. Journal of Biological Chemistry 259, 6013-6018.

Zimmerman, C. L., Appella, E. \& Pisano, J. J. (1977). Rapid analysis of amino acid phenylthiohydantoins by high-performance liquid chromatography. Analytical Biochemistry 77, 569-573. 